Yayın Geliş Tarihi: 17.07.2020

Yayına Kabul Tarihi: 19.11 .2020

Online Yayın Tarihi: 31.12.2020

http://dx.doi.org/10.16953/deusosbil.770639
Dokuz Eylül Üniversitesi

Sosyal Bilimler Enstitüsü Dergisi

Cilt: 22, Say1: 4, Y11: 2020, Sayfa: 1479-1499

ISSN: 1302-3284 E-ISSN: 1308-0911

Araştırma Makalesi

\title{
MODERN BİREYİN BENCILLİĞİ VE AÇGÖZLÜLÜĞÜ: Faust Ekseninde Bir Edebiyat Sosyolojisi Analizi
}

$\ddot{O} z$

Mehmet ANIK*

Bu çalışmanın amact, modern dünya edebiyatının başyapıtlarından biri olan Goethe'nin Faust eseri çerçevesinde, modern bireyin bencilliği ve açgözlülüğ̈̈ ile ilgili analizlerde bulunmaktır. Eserin analizi için nitel araştırma tekniklerinden biri olan içerik analizinden yararlanılmıştır. Bu kapsamda öncelikle çalışmanın giriş kısmında, modernitenin birey tasarımı ve bunun bencillik ve açgözlülük ile ilişkisi üzerinde kisaca durulmuş, akabinde modern bireyin sanat alanında dışavurumcu inşasında öncü rolü olan Goethe üzerinde durulmuş ve son olarak da Faust eseri, modern bireyin bencilliği ve açgözlülüğü çerçevesinde analiz edilmiştir. 60 yıll aşkın bir yazım sürecinin (1770-1831) ürünü olan Faust, manzum bir tragedya olarak, Faust'un hayatı temelinde modern bireyin dramını anlatır. Mefisto'ya ruhunu satan Faust'un en belirgin özelliklerinde biri, sahip olduğu arzularl gerçekleştirme doğrultusunda bencil ve aç gözlü bir birey olması ve bu durumun pek çok yıkım ve ölüme sebep olmasıdır. Bu durum ayn zamanda modern bireyin gelişim sorununa işaret etmektedir. Goethe'ye göre, kendini gerçekleştirme noktasinda, doğayla tamamen bütünleşmek ve içsel sese kulak vermek, bireysel benliğin gelişimi açısından en doğru yol olarak gözükmektedir.

Anahtar Kelimeler: Goethe, Faust, Edebiyat sosyolojisi, Modern birey, Bencillik, Açgözlülük.

Bu makale için önerilen kaynak gösterimi (APA 6. Sürüm):

Anık, M. (2020). Modern bireyin bencilliği ve açgözlülüğü: Faust ekseninde bir edebiyat sosyolojisi analizi. Dokuz Eylül Üniversitesi Sosyal Bilimler Enstitüsü Dergisi, 22 (4), 1479-1499

* Prof. Dr., Bingöl Üniversitesi Fen-Edebiyat Fakültesi Sosyoloji Bölümü, ORCID: 0000-00026560-2470, anik@ bingol.edu.tr 


\title{
SELFISHNESS AND COVETOUSNESS OF THE MODERN INDIVIDUAL: An Analysis of Sociology of Literature on the Axis of Faust
}

\begin{abstract}
The aim of this study is to analyse the selfishness and covetousness of the modern individual within the framework of Faust by Goethe, one of the masterpieces of modern world literature. Content analysis, one of the qualitative research techniques, is used for the analysis of this literary work. Firstly, the individual design of modernity and its relation with selfishness and covetousness are briefly discussed in the introduction of the study, then Goethe, who is a pioneer in the expressionist construction of the modern individual in the field of art, is introduced, and finally Faust is analysed within the framework of the selfishness and covetousness of the modern individual. Faust, a product of more than 60 years of writing (1770-1831), describes the drama of the modern individual as a poetic tragedy on the basis of Faust's life. One of the most prominent features of Faust, who sold his soul to Mephistopheles, is that he is a selfish and covetous individual in order to fulfil his desires, and this situation causes many destructions and deaths. This also points to the development problem of the modern individual. According to Goethe, it is seen the most correct way for the development of self to fully integrate with nature and listen to the inner voice at the point of self-fulfilment.
\end{abstract}

Keywords: Goethe, Faust, Sociology of literature, Modern individual, Selfishness, Covetousness.

\section{GíRiș}

İlk örnekleri Batı dünyasında, Avrupa'da ortaya çıkan modern topluma geçiş sürecinin en önemli neticelerinden biri; geleneksel toplumlarda özellikle kültürel, dinsel ya da toplumsal anlamda ortak değerler etrafinda mutabakatın ve aidiyetin ifadesi olan 'biz' anlayışı yerine, toplumsal aidiyet ve değerlere indirgenmemiş haliyle 'ben' idrakinin giderek daha çok ön plana çıkması olmuştur. Modern dönemde yaşanan bu değişim bir yerde bireyciliğin de zaferi olarak görülmüştür. Toplumsal açıdan kısıtlayıcı unsurlar karşısında otonom bir varlık olarak 'rasyonel birey' anlayışının öne çıkması ve modern dönemin dominant yaklaşımı olan liberal ekonomi ve siyaset anlayışının toplumsallık değil, 'birey' odağında formüle edilmesi bu anlamda önemlidir. Avrupa'da modern dönem öncesini temsil eden Roma Katolik Kilisesi odaklı teolojik otoritenin ana eleştiri konusu haline geldiği Aydınlanma Çağı da rasyonel bir varlık olarak birey kavramının adeta mitolojik bir boyutta yüceltildiği bir dönem olmuştur.

Avrupa'da modern dönemde ekonomik alanda elde edilen zenginliğin ve refahın genelde bireysel girişimler neticesinde ortaya çıktığına dair yaygın değerlendirmeler, 'yükümsüz özne' anlayışında olduğu haliyle, bireyin toplumsal ahlaki değerlere dayalı yükümlülükler ve kısitlamalar etrafında tanımlanmaması gerektiği vurgusunu güçlendirmiştir. Böylece bireyin varoluşunu onun biricikliği etrafında açılayan 
yaklaşımlar giderek ön plana çıkmıştır. Wagner'in dikkat çektiği üzere (2005, s. 15-16), modernlik bireylerin kendi kendilerini yönetme hakkını tanımlarken, bu noktada kuralların nasıl oluşturulması gerektiği konusunda ise herhangi bir rehberlik önermemektedir. I. Kant'ın (2015), Aydınlanma'yı 'insanın kendi aklını bir başkasının kılavuzluğuna ve yardımına başvurmaksızın kullanabilme cesaretini göstermesi’ ve böylece (Orta Çağ'a atfen) 'ergin olamama halinden kurtuluş' olarak nitelendirmesi de bu anlamda kayda değerdir.

Modern dönemde birey, kendi çıkarları doğrultusunda rasyonel davranışlar sergileyen ve bu bireyselliği üzerinden gerçekleştirdiği faaliyetlerle topluma da katkıda bulunan bir varlık olarak yüceltilmektedir. M. Weber'in (1999) modern kapitalizmin gelişmesinde, Protestan ahlakının başlangıçta etkili bir rol oynadığına dikkat çekip, ticaretle uğraşan burjuvazinin, yaptığı ticari etkinliği adeta ilahi bir güdüyle yerine getirmesinin de artan sermaye birikimi ve yeni yatırımların temel nedenlerinden biri olduğu yönündeki tezi, modern dönemde rasyonellik odağında bireysel girişimlerin öneminin vurgulanmasının bir diğer örneğidir. Weber, burjuvazinin kapitalist üretim ve sermaye birikimi doğrultusunda sahip olduğu bireysel girişim ve hırs1, teolojik bir zeminde yorumlayıp anlamlandırdıktan sonra, bu konuda rasyonel açıklamalarda bulunmakta, ancak aynı hırsın ve bencilliğin neden olduğu adaletsizlik ve sömürü ilişkisini ise genelde göz ardı etmektedir.

Aydınlanmacı bilim anlayışı insana doğa üstünde egemenlik vaat etmiş ve bu egemenliğin sağlanmasının aynı zamanda insanoğlunun yetkinliğinin ve özgürlügünün bir sembolü olacağı belirtilmiştir. Bununla birlikte tarihsel alandaki pratikler, bu yöndeki düşüncelerin sonradan keskin şekilde eleştirilmesine ve modernliğe dair çeşitli kaygıların ortaya çıkmasına neden olmuştur. Zira insanoğlunun doğa üstünde egemenlik kurma mücadelesi aynı zamanda insanın insan üzerinde egemenlik kurmasının ve başkalarının bireyselliğinin ve özgürlügünün bastırılmasının da yeni bir tarihi olmuştur. M. Horkheimer'ın ifadesiyle (1998, s. 146), insanın eşya üzerinde iktidar kurma isteğinin yoğun olması oranında, eşyanın onun üzerindeki tahakkümü de ağır olmuş ve insan gerçek bireysel özelliklerinden de o oranda uzaklaşmıştır.

Modern dönem, bireyciliğin yaygınlaştığ 1 bir dönem olmuş ve bu haliyle bu dönem, Adorno ve Horkheimer'in nitelendirmesiyle (2015, s. 53) 'bireycilik çağı' olmuştur. F. B. Dikeçligil yerinde bir tespitle, ben merkezci rasyonel birey modelinin, kapitalist sisteme uygun olan insan tipinin doğasını anlattığına dikkat çekmektedir (2017, s. 191). Bireyin belirli bir toplumsal çerçeveye atıfta bulunmaksızın ya da herhangi bir toplumsallıktan miras alınmaksızın tanımlanma biçimi ve eğilimi giderek baskın hale gelmiş, yaşamı etkileme konusunda bireycilik, önceki dönemlerden çok daha etkin bir hale gelmiştir (Günerigök, 2018, s. 140). 
Modern sosyal bilimler paradigmasına egemen olan rasyonel birey düşüncesi, bireyin her zaman rasyonel davranan bir varlık değil, (olumlu ya da olumsuz anlamda) duygusal ya da irrasyonel davranışlar da sergileyen bir varlık olduğu gerçeğini göz ardı etmektedir. Modern dönemin birey figürü sınırsız arzu sahibi olan, dizginlen(e)memiş faaliyetler icra eden, her şeye kadir bir birey olarak sembolize edildiği oranda, bu durumun sebep olduğu bir çatışmanın ve trajedinin içerisinde bulunmaktan kurtulamamıştır. $\mathrm{Bu}$ dönemde tüketim toplumunun yükselişe geçmesi ve özellikle bireysek girişimcilik odağında yapılan hırs övgüsü ve teşviki; bencil, hedonist ve doyumsuz birey tipinin yaygınlaşmasına uygun bir zemin oluşturmuştur. Şüphesiz bencil ve açgözlü birey tipi ilk kez modern toplumlar ile birlikte ortaya çıkmamıştır. Modernite öncesi insan yaşamında da bu birey tipinin farklı örnekleri bulunmaktadır. Burada vurgulanmak istenen, modernitenin sahip olduğu içsel dinamiklerin bu birey tipinin yaygınlaşmasına en uygun zemini oluşturduğudur. Zira toplumsal ahlaki değerlerden ve sorumluluklardan soyutlanmış rasyonel birey düşüncesi, (arzu edilen bir sonuç olsun ya da olmasın) bencilliği ve açgözlülüğü de bir yerde olağanlaştırmaktadır.

M. Weber (1986), Batı'da ortaya çıkan modern toplumu, büyünün bozulduğu ve rasyonalitenin egemen olduğu toplum modeli olarak izah etmektedir. Oysa gelinen noktada, modernliğin kendi büyüsü sorgulanmaya başlamıştır. Zira iyimser gelecek tasarımına karşın, pratikte yaşanan olumsuzluklar, modernite ile ilgili birtakım endişelerin ortaya çıkmasına sebep olmuştur. E. Fromm (1982, s. 168), normal şartlarda insanın kendi doğasında paylaşmak, vermek, fedakârlık gibi duyguların yaygın olmasına karşın, bireysel çıkarı öne çıkaran modern (kapitalist) toplumlarda dayanışma duygusunun ikinci plana itildiğine ve bu toplumların sadizm, açgözlülük, başkalarına zarar verme, bencillik gibi olumsuz güdüleri beslediğine dikkat çekmektedir. Nihayetinde kazanç-kâr-mülkiyet temelleri üzerinde bireysel hırsı teşvik eden bir toplumun, 'ele geçirmek' ve 'sahip olmak' eğilimleri taşıyan bir birey tipinin yaygınlaşmasına neden olduğu açıktır. Hedonist bir duyguyla kişisel arzularına erişmek için her türlü ahlaki ilkeyi çiğnemeyi göze alan, kendisi başkalarına saygı duymaktan imtina etse de kendi kişisel çıkarları için kendisine saygı duyulmasını bekleyen, başkalarına zarar verip vermediğine genelde aldırmayan ve özeleştiriden yoksun olup, kişisel hırsı doğrultusunda davranışlar sergileyen bencil ve açgözlü bir birey tipi giderek yaygınlık kazanmaktadır.

Bu çalışmanın konusu, modern dönemin ünlü metinlerinden Goethe'nin Faust eseri çerçevesinde, modern bireyin açgözlülüğü ve bencilliği ile ilgili bir edebiyat sosyolojisi analizidir. Bu analiz sürecinde, nitel araştırma tekniklerinden biri olan içerik analizi tekniğinden yararlanılmıştır. Yöntemsel açıdan öncelikle, modern bireyin sanat alanında inşa edilmesinde önemli rolü olan Goethe'nin edebi kimliği üzerinde kısaca durulmuş, akabinde ilk cildi 1806, ikincisi ise 1832 y1lında 
yayınlanan ve 60 yılı aşkın bir yazım sürecinin (1770-1831) ürünü olan ünlü eseri Faust, modern bireyin sahip olduğu bencillik ve açgözlülük duygusu çerçevesinde analiz edilmiştir. Goethe, Aydınlanma Çağı'nda ön plana çıkarılan rasyonel birey figürüne belirli açılardan eleştirel yaklaşan ve bireyin hayal gücü ve duygu sahibi bir varlık olduğu hususuna eserlerinde dikkat çeken bir isim olması anlamında önemlidir.

\section{MOREN BİREYIN SANAT ALANINDA DIŞAVURUMCU İNŞASI: J. W. VON GOETHE VE FAUST}

Aydınlanma döneminde doğan J. W. Von Goethe, ailesinin sunduğu imkanlarla iyi bir eğitim almış, Weimar Almanya'sında siyasi birtakım görevlerde bulunmuş, ayrıca bir süre İtalya' da yaşamış ve burada kültür, sanat, siyaset gibi alanlardaki gelişmelere doğrudan tanık olmuştur. W. Shakespeare, Voltaire, G. E. Lessing, D. Diderot, J. G. Hamann, J. G. Herder, J. J. Rouesseau, G. Vico, B. Spinoza, G. Arnold gibi düşünürler, Goethe üzerinde etki bırakan isimler olmuş, ayrıca çağdaşı olan F. Schiller ile de karşılıklı etkileşim içerisinde olmuştur. Goethe sadece Alman edebiyatının değil, dünya edebiyatının önde gelen isimlerinden biri olup, romantizm akımının en merkezi figürlerinden biri olarak kabul edilmektedir. İspanyollar için Cervantes, İngilizler için Shakespeare, Fransızlar için Racine ya da İtalyanlar için Dante ne ise, Almanlar için de Goethe odur. Dünyada İspanyol dilini ve kültürünü yaymak amaciyla kurulan Cervantes Enstitüsü örneğinde olduğu gibi Alman dilini ve kültürünü yaygınlaştırmak için kurulmuş olan ve Türkiye'de de şubeleri bulunan Goethe Enstitüsü'ne Almanya'nın sembol ismi olarak görüldüğü için Goethe'nin ismi verilmiştir. Alman edebiyatının 'Altın Çağ'ı olarak kabul edilen 18. yüzyıl ile 19. yüzyılın ilk dönemleri arasındaki periyotta, Goethe'nin edebiyat ve entelektüel yaşam üzerindeki etkisinden dolayı 1770-1830 yılları arasındaki Alman entelektüel tarihi, aynı zamanda 'Goethe Çağı' (Goethezeit) olarak da adlandırılmaktadır. ${ }^{1}$

1 'Goethe Çağı' ile ilgili ayrıntılı okuma için bkz. Lukacs (2011), Pizer (2011) ve Richards (2002). Çalışmaları genelde Alman edebiyatı ve entelektüel tarihi üzerine yoğunlaşan N. Boyle (1992) ise, 'Goethe Çağı' kavramının Goethe'nin doğru anlaşılmasının önünde bir engel olduğunu, böyle bir çağın aslında hiç olmadığını ve yaygın kanının aksine, edebiyat kariyerinin ilk beş yılı hariç, Goethe'nin asla bütün bir neslin taklit etmeyi seçtiği bir model olmadığını belirtmektedir. Boyle'un bu konudaki değerlendirmesinde, Goethe'nin kendisi tarafindan yapılmayıp, sonradan üretilmiş olan bu tanımlamayı, özellikle onun sözlerine atıfta bulunarak yanlışlamaya çalışması ya da bütün bir nesil tarafindan taklit edilmiş olma gibi sübjektif ölçütler belirtmesi ise eleştiriye açık bir husustur. Boyle (2008, s. 58), 'Goethe Çağı' yerine, özellikle F. 1483 
G. Simmel (2015, ss. 216-217), 19. yüzy1lda 'benzersizlik bireyciliğgi' olarak nitelendirdiği bir anlayışın ön plana çıkmaya başladığını ve bu türden bir anlayışının yaygınlaşmasında, romantizmin duyguya ve deneyime dayalı bir temel oluşturarak, büyük rol oynadığını belirtmektedir. Ona göre Schleiermacher bu bireycilik anlayışının metafizik temelini, Goethe ise sanatsal temelini oluşturmuştur. Aydınlanma döneminin birey anlayışına eleştirel yaklaşan romantizmde, bireysel benlik sonsuz bir karşıtlıklar silsilesi barındırır ve her bireyin hayatının anlamı, diğer herkesten farklılığında, doğasının ve eylemlerinin benzersizliğinde yatmaktadır. Simmel (2015, s. 328), Aydınlanma düşüncesinde tarihsel bağlardan kurtulmuş birey fikrinin ön planda olduğunu, ancak gerek Goethe gerekse romantizm anlayışında, kendisini diğerlerinden ayırt etmek arzusu baskın olan birey anlayışının dikkat çektiğini belirtmektedir. Aydınlanma düşüncesinden farklı olarak artık vurgulanan; her bireydeki 'genel insan' değil, insanın nitel eşsizliği ve ikame edilemezliğidir.

Edebiyat alanında Goethe'nin en önde gelen temsilcilerinden biri olduğu romantik dişavurumculuk, Aydınlanma düşüncesinin modern birey tasarımına karşı genelde tepkiler içerse de kısmi benzerlikler de barındırmaktadır. C. Taylor'1n dikkat çektiği üzere, 18. yüzyılın sonunda romantik dişavurumculuk ile birlikte ortaya çıkan hayat anlayışı; gelenek, din ya da siyasal bir otorite tarafından dışarıdan herhangi bir hayat modeli dayatılmaksızın, her bireyin yolunu kendisi bularak, hayatını özgürce yaşaması gerektiğini savunmaktadır (Taylor, 2014, ss. 557-558). Bu noktadaki yaklaşım Aydınlanmacı perspektifle paralellikler taşısa da dışavurumculukta, Aydınlanma'nın bağımsız akıl ve nesnellik vurgusu karşısında, öznelleşmenin göz ardı edilmiş olan önemi vurgulanmaktadır. Başka bir ifadeyle, Aydınlanma'nın nesnelleştirilmiş dünya tasarımına karşı, romantik dışavurumculukta öznelleştirilmiş bir dünya ön plana çıkmakta ve (bireydeki) içsel dünya ile (doğadaki) dışsal dünya arasında bir bağlantı, bir bütünlük sağlanmaya çalışılmaktadır. Bu noktada bilgiye tek erişim vasıtası olarak aklı gören yaklaşım eleştirilmekte ve çıkarcı aklın hakikate erişimi engelleyebileceği düşüncesinden hareketle, hakikate erişim vasıtası olarak içsel sese önem verilmektedir. $\mathrm{Bu}$ yaklaşımda tabiat, iyilik barındıran içsel bir kaynaktır ve tabiatla bütünleşme ve iyi bir hayata sahip olmanın koşulu da başkalarını model alma ihtiyacı duymaksızın içsel sese kulak vermektir. Bu durum, her bireyin sahip olacağ1 tecrübenin emsalsizliğine de göndermede bulunmaktadır.

Schiller ve I. Kant isimlerini ön plana çıkardığı bu dönemi, ‘İdealizm Çağı’ olarak nitelendirmeyi tercih etmektedir. 
Goethe, Almanya'da 18. yüzyılda ortaya çıkan 'Yeni Hümanizm' (Neuhumanismus) akımının önemli temsilcilerinden biri olarak görülmektedir. Onun şiiri 'insanlığın evrensel mülkiyeti' olarak nitelendirmesi bu anlamda ilgi çekicidir. Yine bu anlamda 'dünya edebiyatı' (weltliteratur) fikrini öne sürmesi kayda değerdir. Eckermann ile yaptığı söyleşide, insanların vatansever bir sanat anlayışı veya vatansever bir bilim anlayışının olmadığına yakın zamanda ikna olmalarını umduğunu söyleyen Goethe, her iyi şey gibi bilim ve sanatın tüm dünyaya ait olması gerektiğini belirtmektedir. Çağdaş olanı önems emekle birlikte tarihselliğe de önem veren Goethe, söz konusu iki alanın, geçmişten miras alınanlar göz ardı edilmeksizin, çağdaş özgür ilişkilerle geliştirilmesi gerektiğini savunmaktadır (Eckermann, 2007; Strich, 1949).

Kişisel hayatında devlet adamı ya da bilim insanı gibi farklı birtakım rolleri olsa da Goethe özellikle edebiyat alanında yazdığı eserler ile modern dünya edebiyatında etkili bir isim olmuş ve bu eserleriyle, Almanya'dan ve dünyanın farklı yerlerinden isimler için ilham kaynağı olmuştur. Goethe'nin, Alman edebiyatında 18. yüzyılın ikinci yarısında bir süre dominant yaklaşım olarak beliren ve Aydınlanmacı rasyonalizme mesafeli yaklaşıp, duygu sahibi bir varlık olarak bireyciliği ön plana çıkaran 'Sturm und Drang' hareketinin etkisindeyken yazdığ1; aşırı duyarlı yönüyle, modern melankolik bireyin sembolü olarak görülen ve karşılıksız aşkı nedeniyle intihara sürüklenen genç sanatçı Werther'in hazin öyküsünü anlattığı Genç Werther'in Acıları (2019), Franz Kafka'nın modern bireyin kendisine yabancılaşmasını, yalnızlığını, kısıtlanmasını, çaresizliğini ve dışlanmasını ele aldığ1 ünlü eseri Dönüşüm'e (2020) ilham kaynağ1 olmuştur. U. Plenzdorf, aynı eseri 20. yüzyılın ikinci yarısında Alman toplumunun içinde bulunduğu duruma uyarlama yoluna giderek The New Sorrows of Young W. (2015) adlı eseri yayınlamıştır. Goethe' nin Avrupa edebiyatı üzerinde önemli etkileri olan bir diğer romanı Wilhelm Meister'in Çıraklık Yılları (2018), Samuel Butler'in Tüm Insanlar Gibi (2010) eseri için ilham kaynağı olmuştur. Bu iki romanın ana karakterleri Wilhelm Meister ve Ernest Pontifex, yaşadıkları hayal kırıklıkları ve mutsuzluklara karşın, hayata tutunma çabaları, ahlaki ve entelektüel gelişim ile bireysel kimlik mücadelesi verme yönleriyle benzerlikler taşımaktadırlar. $\mathrm{Bu}$ eserden ilham alan bir diğer isim de Ernest Maltravers (2010) romanını yazarken E. B. Lytton olmuştur.

D. Barry, Goethe'nin J. Joyce üzerindeki etkisini Faust ve Ulysses eserleri arasındaki karşılaştırmaya dayalı bir çalışmayla ortaya koymaktadır (Barry, 1992). Henrik Ibsen'in Norveç halk masallarından hareketle yazdığ 1 manzum tragedya Peer Gynt (2009) eseri, Goethe'nin Alman halk masallarına dayanan manzum tragedyası Faust ile yazım tarzı ve tekniği açısından büyük benzerlikler 1485 
taşımaktadır. A. Schopenhauer, Yaşam Bilgeliği Üzerine Aforizmalar'da (2018) Goethe'ye pek çok atıfta bulunurken, F. Nietzsche, Tragedyanın Doğuşu'nda (2007), Antik Yunan anlayışı ve modern Batı kültürü arasında çeşitli karşılaştırmalar ve değerlendirmeler yaparken Goethe'ye ve özellikle Faust'a pek çok atıfta bulunur. Nietzsche'nin farklı çalışmalarında da bu etkiyi görmek mümkündür. Nietzsche'nin 'üst-insan'1 için Faust önemli bir karakterdir. O. Spengler (1978), Batı uygarlığının ilerlemeci, evrenselci ve tahakküm içeren yaklaşımını eleştirirken, Faust yararlandığı başlıca kaynaklardan biri olmuştur. Burjuvazinin son entelektüel devrimlerinden birinin Almanya'da Goethe döneminde gerçekleştiğini belirten ve Goethe'yi Hegel'le birlikte tarihi diyalektiğin büyük bir siması olarak nitelendiren G. Lukacs (2011, s.187), Goethe' nin çatışan farklı eğilimleri uzlaştırarak, Faust ile benzersiz bir eser ortaya koyduğunu ileri sürer. Faust'un etkisi; müzik, tiyatro, opera, drama, sinema gibi farklı alanlarda da yansıması olacak şekilde oldukça geniş bir alanı kapsamaktadır.

J. M. van der Laan (2007), Faust ya da Faust benzeri figürlerin; antik çağda, pagan ve Hristiyan içeriklerde, erken modern, modern ve postmodern dönemde, sanat ve müzikte ve Almanca, İngilizce, İspanyolca, Fransızca, Rusça, Çekçe, Macarca, Portekizce, İtalyanca, Romanca gibi Batı'nın tüm ana dillerinde bir şekilde mevcut olduklarını belirtmektedir. Başka bir ifadeyle Faust, ilk kez Goethe ile birlikte ortaya çıkan bir figür değildir. Günahkarlığı, mürtetliği, işkenceye maruz kalmış kurbanı, gizemli ve yasaklanmış bilginin peşinde koşan kişiyi veya ruhunu şeytana satan insanı sembolize eden Faust'un farklı versiyonlarına eski çağlardan beri Batı dünyasında rastlanmaktadır. Johann Spiess tarafindan 1587 yılında yayınlanan Faustbuch, Christopher Marlowe tarafindan 1588'de yayinlanan The Tragical History of the Life and Death of Doctor Faustus ve Thomas Mann tarafindan 1947 yılında yayınlanan Doctor Faustus: The Life of the German Composer Adrian Leverkühn As Told by a Friend, ${ }^{2}$ Goethe'nin Faust'u dışında bu konuda en çok bilinen Faust anlatılarıdır. Cervantes'in yaşadığ 1 dönemde popüler olan şövalyelik romanlarından esinlenerek, bu eserleri eleştirmeye ve aşmaya yönelik modern bir anlatı olarak Don Quijote'yi (2019a; 2019b) yazması örneğinde olduğu gibi Goethe, Faust konusunda Batı dünyasında ve Alman halk öykülerinde eskiden beri var olan bu gelenekten etkilenerek, modern hayata yönelik endişe ve huzursuzluğu yansitmak üzere Faust'un modern bir manzum tragedya olarak özgün bir biçimini yazmıştır. M. Berman (2013, s.63), Goethe'nin Faust'unun tarihsel perspektif zenginliği, derinliği, moral imgelem, politik bilgi, psikolojik duyarlılık ve öngörü yönlerinden diğer tüm örnekleri

\footnotetext{
${ }^{2}$ Son iki çalışmanın Türkçe yayınlanmış çevirileri için bkz. Marlowe (2018) ve Mann (2018).
} 
geride bıraktığını belirtmektedir. I. Watt (2016, s. 258) da Faust'u modern bireycilikle ilgili eserler arasında en önemli başarıyı yakalamış eser olarak nitelendirmektedir.

\section{MODERN DÜNYANIN BENCÍL VE AÇGÖZLÜ BİR BİREYİ OLARAK FAUST}

Modern romanın ilk örneği olarak kabul edilen Don Quijote'nin başlangıç kısmında Cervantes'in, dönemine egemen olan yazın anlayışını eleştirip, modern okura yönelik birtakım mesajlar vermesi örneğinde olduğu gibi Goethe de Faust'un giriş bölümünde tiyatro müdürü, tiyatro yazarı ve soytarı arasında geçen diyaloglar üzerinden, tiyatro eseri ve izleyici kitle ile ilgili eleştirel bir tavır ortaya koyar. Tiyatro müdürü, daha çok gelir elde etmek için tiyatroyu hıncahınç dolduracak bir seyirci kitlesinin özlemi içindedir ve bunu sağlamanın yolunun iyi bir tiyatro eserinden geçtiğini bildiği için de tiyatro yazarından bu konuda talepte bulunur:

“(..)

Görmek isterim kalabalı̆̆ elbette,

Sel gibi çadır tiyatromuza akan

(...)

Gündüz vakti, saatler henüz dördü göstermeden,

Bilet almak için mücadele veren,

Sanki kıtlıkta firının kapısında ekmek bekleyen,

Tek bir bilet için birbirini çiğneyen,

Bu mucize her tür insanı etkiler,

Yazardir ancak bu etkiyi yaratacak:

Dostum, gerçekleştir hemen bunu!" (Goethe, 2016, ss. 23-24).

Tiyatro müdürünün bu yöndeki talebi karşısında yazar ise, bu konuda bask1 altına alınmasını 'uşak gibi görülmek' şeklinde nitelendirip, bunun doğanın yazara verdiği insanlık hakkının alçakça çiğnenmesi olduğunu belirtir ve bu talebe karşı çıkar. İnsanlığın kudretini temsil ettiğine inanan yazar, ticari kaygıları ön planda tutan, sanat değeri düşük bir çalışma yerine, sonraki okurların da okuduklarında takdir edecekleri nitelikli bir çalışma yapmanın derdindedir. Zira yazara göre: 
“(...)

Parıldayan şey, bir anliktır sadece,

Gerçek olan uzanır gelecek nesillere” (Goethe, 2016, s. 24).

Tiyatro yazarı, 'anlık beklentilerin aksine, sanat yönü güçlü' bir eser oluşturup, modern okur ve izleyiciye ulaşmayı amaçlamaktadır. Böylece, daha dar bir kitleye hitap eden klasik dönem anlayışının ürünü bir metin yerine, gelecek nesillere de ulaşacak modern bir metin hedeflenmektedir. Buna karşın soytarı da tiyatro müdürü gibi geleceğe de kalacak bir eser kaygısından öte, mevcut halk kitlesini memnun edip eğlendirecek bir çalışma ortaya koymanın gerekliliğini vurgular. Tiyatro müdürü, izleyici kitlesinin beklentisine uygun düşecek şekilde, içinde çokça olay geçen ve farklı etkinliklere imkân veren bir tiyatro metninin oluşturulması yönünde talepte bulunur. Tiyatro müdürü ve soytarının başlıca kaygısı, eserin edebi değerinden bağımsız olarak, mevcut kitlenin beğenisini elde edecek ve böylece maddi kazanç sağlayacak bir eserdir. Bundan dolayı tiyatro müdürü, 'kuvvetli içkiler içmek istiyoruz' deyip, yazardan halk kitlesini çokça eğlendirip, kendinden geçirecek bir eser ortaya koymasını söyler. Bu diyaloglarda Goethe, idealist bir tutum taşıyan tiyatro yazarı aracılığıyla, yazarın modern izleyiciye ulaşma ve özgürlük arayışını ifade eder.

Bu diyalogların sonrasında eser asıl olarak, Tanrı, melekler ve Mefistofeles (şeytan) arasında gökteki prolog ile başlar. Buradaki diyaloglar, Hz. Adem'in yaratılması sonrasında kendisine Tanrı tarafından biçilen özel konum ve İblis'in buna kibirli tepkisi şeklinde, tek tanrılı dinlere ait teolojik metinlerde geçen anlatılarla çeşitli benzerlikler taşır. Mefistofeles, Tanrı'nın huzurunda hazırda bulunan baş melekler Rafail (İsrafil), Cebrail ve Mikail'e karşı alaycı ve kibirli bir tutum takınır ve dünyevi yaşam ile ilgili çeşitli şikayetlerde bulunur. Tanrı, Mefistofeles'e kulu Faust'u tanıyıp tanımadığını sorduktan sonra, yakında Faust'u aydınlığa kavuşturacağını söyler. Bunun üzerine Mefistofeles, Tanrı ile iddiaya girerek, Faust'u kendi yoluna çekeceğini ileri sürer. Bu iddia karşısında Tanrı tarafından, Mefistofeles'e iddiasını ispatlaması için Faust'un yeryüzündeki yaşam süresi dahilinde kendisine mühlet verildiği belirtilir. Bu diyaloglarda Faust, sadece kendisini değil, adeta bütün insanlığ 1 temsil eder gibidir.

Eserin sonraki bölümünde okur, Faust karakteriyle tanışır. Don Quijote gibi Faust'un da olay örgüsü modern dönemde, ancak Orta Çağ kalıntılarının tamamen ortadan kalkmadığı bir toplumsal düzende geçer. Simyayla da uğraşan bir tabibin oğlu olan Faust, tıp öğrenimi sonrasında babası gibi doktor olmuştur. 
Felsefe, hukuk ve teoloji ile de akademik düzeyde ilgilenen Faust, çevresinde saygı gören bir isimdir. Bununla birlikte sahip olduğu farklı akademik uğraşlar, kendisini kişisel olarak tatmin etmediği için bireysel olarak kendini gerçekleştirme arayışı içerisindedir. Kişisel hayatında mutsuz olan Faust, Aydınlanmacı bireyin bilime duyduğu büyük inancı sembolize eden asistanı Wagner'a hayata dair özlemlerinden bahsetmesinin hemen sonrasında, bir fino kılığgnda kendilerine yaklaşan Mefistofeles ile karşılaşır. Mefistofeles, Faust'la olan görüşmelerinde öncelikle onu bilim ve mantıktan uzaklaştırır ve ona dünyevi dertlerin ve acıların ötesinde bir yaşam vaadinde bulunur. Eğlence ve zevklerin büyülü dünyası ile ilgili ayartıcı telkinlerde bulunarak, Faust'u kontrol altına almaya çalışan Mefistofeles, Faust'un bu dünyadaki her arzusunu yerine getirme ve bu doğrultuda ona hizmet etme karşılığında, öbür dünyada onun kendisinin hizmetkarı olması yönünde bir anlaşma yaparak, ruhunu satın alır. Wagner'ın yerini alan Mefistofeles, Faust ölünceye kadar artık onun bu dünyadaki hem yeni asistanı hem de yol gösterenidir.

Faust gerek bilim gerekse metafiziğge dayalı bilginin kendisini yüceltip mutluluk getirmediğini belirterek, geleneksel dünyadan uzaklaşmaya başlar ve artık sadece dünyevi zevkler peşinde koşan bencil, doyumsuz ve açgözlü bir bireye dönüşür. Mefistofeles ile tanıştığında 50 yaşında olan Faust, kendisine sunulan büyülü içkiyle 30 yıl gençleşir ve gördüğünde güzelliğine hayran kaldığı Gretchen (Margarete) onun başlıca tutkulu hedefi olur. Modern bireyin ihtiras dolu dünyevi tutkularına sahip olan Faust, geleneksel dünyanın saflığ 1 içerisinde bir hayat süren Gretchen'i ayartıp, ona bir an evvel sahip olmaya yönelik, bencilce birtakım duygular besler. Mefistofeles'ten Gretchen'i kendisine ayarlamasını isteyen Faust, inançlı ve son derece masum bir genç kızı sembolize eden Gretchen'i, Mefistofeles'in yardımı ve birtakım söz oyunları neticesinde ayartıp, kendisine aşık eder ve bir süre sonra da ona sahip olur.

Faust'un hayatına dahil olması, Gretchen'in ailesinin yok olmasinın da başlangıç noktası olur. Önce annesi, akabinde de kardeşi Valentin hayatını kaybeder. Faust ile tanışmadan önce, ahlak ve masumiyet konusunda diğer kızlara örnek olarak gösterilen kız kardeşinin, Faust ile evlilik dışı bir ilişkisi olduğunu öğrenen Valentin, Faust ve Mefistofeles ile karşılaştığında, onlara bunun hesabını sormak ister. Ancak bu karşılaşmada Mefistofeles'in Faust'u tahrik etmesiyle Valentin, Faust tarafından öldürülür. Gretchen ile birliktelik yaşadığ 1 gece, sevgilisinin annesine fazladan uyku ilacı vermesine ve ölümüne neden olan Faust, Gretchen'in kardeşi Valentin'in de böylece katili olur. Faust'la evlilik dişı ilişkisinden bir bebeği olan Gretchen, bütün bu yaşadıklarından sonra bilincini bir an kaybederek, göğsüne sıkıca bastırdığı çocuğunun nefessiz kalarak ölmesine 
sebep olur. Aile kurumunu hayatının merkezine koyan geleneksel değerlere sahip olan, ancak Faust ile tanışmasından sonra bu geleneksel kimliğinden gittikçe uzaklaşan Gretchen'in ailesi böylece yok olur.

Gretchen'in tutuklanıp idama mahkûm edilmesi karşısında bir süre vicdan azabı çeken Faust, olanlardan dolayı Mefistofeles'i itham ettiğinde, Mefistofeles olanlar karşısında aslında onun hiç de masum olmadığına şu sözlerle karşılık verir: "Kimdi onu felakete sürükleyen? Ben mi yoksa sen mi?" (Goethe, 2016, s. 231). Faust olanlar karşısında kısa süre vicdan azabı çekse de Gretchen'in hayatının alt üst olmasına sebep olan bencil ve açgözlü ihtirasını görmezden gelir ve özeleştiriden sakınıp, olanlar karşısında Mefistofeles'i itham etme yoluna gider. Faust örneğinde modern birey, bencillik ve açgözlülük içeren ihtiraslara sahip olduğu oranda, saplantılı tutkularının esiri olmakta ve yaşanan olumsuzluklar karşısında başkalarını itham ederken, kendisiyle ilgili özeleştiri sürecinden ise kaçınmaktadır.

Burada önemli sorunlardan biri de bilgi ve eylem arasındaki ilişki sorunudur. Goethe için sorun, doğru olan ya da yanlış olana dair ahlaki bir kodu bilmemek değil, bilgi ve eylem arasındaki ya da ahlak ve epistemoloji arasındaki ilişki sorunudur. Ahlaki olarak bir konuda yapılması ve yapılmaması gerekeni bilmek, bu bilgiyle örtüşen bir eylemin ya da davranışın garantisi olmamaktadır. Bilgi düzeyinde ahlaki birtakım kodlara sahip olsa da birey, eylem noktasında bu ahlaki kodların zıttı olarak yorumlanabilecek birtakım davranışlar sergileyebilmektedir. Faust, Gretchen'in sahip olduğu masumiyeti görmesine rağmen, bencilce bir duyguyla ona bir an evvel sahip olmaya çalışmış ve bunun için Gretchen'in hayatını alt üst etmekten geri kalmamıştır. Bu konudaki kısa süreli vicdan azabı, gerçek bir bireysel iç hesaplaşmaya dönüşmemiş, idama mahkum edilmiş olan Gretchen'i başlangıçta kurtarmayı düşünse de sonrasında kendi sebep olduğu bu felaket ile onu baş başa bırakmıştır.

Modern döneme ait bu tragedyanın ilk kısmında, Faust karakterinin geçirdiği dönüşüm süreci bir yönüyle, modern bireyin tamamen dünyevi arzular peşinde koşan, ele geçirme ve hükmetme yönündeki açgözlü ihtirasını, bencilliğini ve kapitalist gelişim sürecini ifade etmektedir. Faust'un maddi güç, dünyevi iktidar ve cinsellik arzusu gibi hususlar doğrultusunda geçirdiği bu ontolojik dönüşüm, sadece onunla sınırlı olmayıp, eserin yazıldığı modern dönemin Batı'ya özgü kapitalist gelişim ve dönüşüm ruhunu da yansıtmaktadır. W. Sombart'ın Aşk, Lüks ve Kapitalizm'de (2016) dikkat çektiği üzere, aşkın dünyevileştirilmesinin bir parçası olarak cinsellik, kapitalizmin başlica simgelerinden biridir. Faust'un başlıca özelliklerinden biri de aşkı cinselliğe indirgemiş olmasıdır. 
Eserde Faust, dünyevi ihtiraslara kapılıp dönüşüm geçiren, bencil, açgözlü, ahlaki ilkelerden uzak, modern ve seküler entelektüel bireyi sembolize etmektedir. Mefistofeles, toplumsal değerleri küçümseyen, ayartıcı ve güvenilmez biri olsa da eserin bazı kısımlarında realist yönüyle de dikkat çekmektedir. Gretchen karakteri başlangıçta masumiyeti sembolize etse de Faust'un ihtirasının bir parçası olması ve ona teslim olmasiyla da bu masumiyetini yitiren ve kirlenen bireyi sembolize etmektedir. Bir yönüyle Gretchen karakteri, kendisiyle temsil edilen geleneksel değerlerin, Faust'un temsil ettiği modern tutkular karşısındaki yenilgisini sembolize etmektedir. Eserin ilk kismının sonunda, Gretchen zindanda tutukluyken, bütün olanlardan dolayı derin bir pişmanlık duyup, kimliğini sorgular ve tövbekâr olur. Gökten gelen ses, tövbesinin kabul edildiğini belirtir.

Eserin ilk kısmında Faust, bu dünyaya ait bir kahraman olma niteliği taşırken, karakter sayılarının arttığı ve mitoloji odaklı sembolizmin daha çok ön plana çıktığı ikinci kısımda ise artık bağlantısı sadece bu dünyayla sınırlı bir varlık değildir. Faust ve Mefistofeles bulundukları sarayda, ordunun maaş ücretlerini ve saray masraflarını artık karşılayamaz bir noktaya gelen ve büyük mali sorunlarla uğraşan imparatora, altın ve gümüşe karşılık gelecek şekilde kâğıt paranın kullanılmasını önerip, bu mali darboğazdan kurtuluşu sağlarlar. Meydana gelen bu refahın mimarları olarak da ödüllendirilirler. Faust, imparatorun ödüllendirmesiyle, hâkim tepesinde güçlü bir kalenin olduğu, geniş toprak sahibi bir soylu olur. Eserin sonraki kısımlarında görüleceği üzere Faust bunlarla yetinmez ve doyumsuz bir birey olarak mülkiyetini genişletmeye çalışır.

Eserin bu kısmında, ilk bölümdeki Gretchen karakterinin yerini bu kez Helena alır. Faust, Zeus'un Sparta kraliçesi Leda ile kaçamak ilişkisinden doğan, efsanevi güzelliğiyle bilinen ve Truva savaşına neden olan mitolojik kahraman Helena'ya âşık olur ve onunla evlenir. Euphorion adında bir çocukları olur, ancak genç yaşta hayatını kaybeder ve akabinde Helena da hayata veda eder. Gretchen gibi Helena da Faust ile tanışmasının sonrasında benlik duygusunu ve kendi gerçekliğiyle olan ilişkisini kaybeden biridir. Bir aileye sahip olsa da Gretchen gibi o da kendisiyle birlikte bu ailenin yok oluşuna tanık olur.

Eserin bu kısmında Goethe'nin çokça mitolojik kahraman tercihinde bulunması oldukça kayda değerdir. Goethe, Antik Roma ya da İskandinavya mitolojisinden de kahramanlara eserinde yer verse de baskın olarak Antik Yunan mitolojisindeki karakterlere başvurur. C. Taylor, Goethe'nin özellikle Antik Yunan mitolojisi kahramanlarına dayalı bir sembolizme başvurmasını dışavurumcu yaklaşım etrafında açıklamaktadır. Ona göre Goethe, romantik dışavurumculukta öne çıkan tabiatın bir kaynak olarak algılanması gerektiği fikrini 
en etkili şekilde ifade eden kişidir. Taylor, dışavurumcu bütünlük idealinin, Hristiyanlığın aşkın özlemlerinden ziyade, antik paganların bakış açısıyla daha çok uyum sağladığını ve Yunanlıların bütünle uyumlu bir tavırla özdeşleştirilmelerinin, Alman romantiklerinin ana temalarından biri olduğunu belirtmektedir (Taylor, 2012, s. 620).

Antik Yunan mitolojisindeki kahramanların önemli özelliklerinden biri; dizginsiz bir ihtirasa, bencilliğe ve açgözlülüğe sahip olmaları ve bu noktada gerek mitolojik tanrılar ve tanrıçalar (ölümsüzler) olarak kendi aralarında gerekse de insanlarla (ölümlülerle) birtakım çekişmeler içerisinde olmalarıdır. Mitolojik kahramanlar noktasında üzerinde durulması gereken önemli hususlardan bir diğeri de Aydınlanmacı modernizmde bireyle ilgili yapılan vurgunun bir yönüyle mitolojik bir boyut içerdiğidir. Zira mitolojik kahramanlarda olduğu gibi Aydınlanmacı otokratik bireye de adeta tanrısal bir kudret atfedilmiştir. Bilimin rehberliğinde modern bireyin tamamen özgür bir varlık olarak, doğaüstünde mutlak egemen güç olacağına dair yapılan vurgular, pratikte mit olarak kalmış ve bu durum insanın insan üzerinde tahakkümünde de yeni bir evre olmuştur. $M$. Horkheimer ve T. W. Adorno'nun deyimiyle (1995, s. 16), 'mit zaten Aydınlanmadır ve Aydınlanma mitolojiye geri dönmektedir.' Goethe'nin metnin özellikle ikinci kısmında mit ve gerçekliği bir araya getirmesi ve Faust'un aşkın bir gerçekliğin peşine düşmesi bu anlamda da kayda değerdir.

Metnin sonlarında Mefistofeles, imparatorun sefa düşünn̈ olmasıyla, memleketin kargaşaya ve iç savaşa sürüklendiğini, herkesin birbirine düşman olduğunu, kardeşin kardeşi öldürdüğünü ve bu duruma isyan eden halkın kendilerine huzur sağlayacak bir imparator arayışına girerek, ülkeyi tekrardan canlandırmayı ve böylece birlik ve adaleti sağlamayı umduklarını belirtir (Goethe, 2016, ss. 497-498). Buradaki alegorik anlatım bir yönüyle Almanya'y1 tasvir etmektedir. Zira (Goethe döneminde) prenslikler arasında kavgaların yaşandığ Almanya'nın (Prusya) önemli sorunlarından biri, ulusal birliğini sağlayamamış olmasıdır. Lukacs (2011, s. 192), Goethe'nin Alman tarihiyle doğru şekilde ilişki kurmaya önem verdiğini ve diğer Alman şairlerden de bunu yapmalarını beklediğini ifade etmektedir. M. Berman ise (2013, s. 69), Goethe ve çağdaş1 Alman aydınlarının, toplumlarını İngiltere, Fransa ve Amerika ile kıyaslayıp, geri kalmışlığa vurgu yapan ilk aydınlar olduğunu belirtmektedir. Bu 'az gelişmişlik kimliği' kimi zaman bir utanç, (Alman romantik muhafazakarlarında olduğu gibi) kimi zaman bir gurur kaynağı, çoğu zaman da ikisinin bir karışımıydı.

İmparatora tekrar yardım eden Faust ve Mefistofeles, iç kargaşanın sona ermesine ve zafer elde edilmesine katkıda bulunurlar. Faust hükmettiği toprakları 
böylece daha da genişletir ve malvarlığını iyice arttırır. Kendisine ait topraklarda bir sarayda yaşamaya başlayan Faust, sahip olduğu onca malvarlığına rağmen, yine tipik bir kapitalist gibi doyumsuzluğuyla ön plana çıkar. Faust sergilediği eylemlerde, yine ahlaki ilkelerden uzak olan, haz peşinde koşan bencil ve açgözlü bir modern entelektüel bireydir ve bu yönüyle eserin ilk kısmıyla arasında tutarlılık gösterir. Goethe, Faust karakteri üzerinden modern bireyin çelişkilerini sergilemeye böylece devam eder. Faust bazen kendisinde Tanrısal bir kudret görecek kadar büyük hissederken, bazen ise kendisini bir cüce ya da ayaklar altında ezilen bir solucan gibi küçük hisseder.

Faust, bencil ve açgözlü ihtirasıyla, kendi yaşam konforunu arttırma adına, başkalarının her türlü yaşam konforunu bozma hakkını kendinde gören bir bireydir. İçinde 1hlamur ağaçlarının olduğu ve yaşlı bir çiftin yaşadığı araziye, 'manzaramı bozuyorlar' düşüncesiyle, gözcü kulesi dikmek için göz koyan Faust, önce ıhlamur ağaçlarını yaktırır, akabinde ise yaşlı çifte yeni bir konut verilerek, yaşadıkları yerden çıkartılmalarını emreder. Ancak olaylar Faust'un beklediği gibi gelişmez. Mefistofeles'in de dahil olmasıyla zorbalıkla evlerinden çıkartılmaya çalışılan yaşlı çiftin korkudan öldükleri belirtilir (Goethe, 2016, ss. 542-543). Eserin birinci kismında Gretchen ve ailesinin yok olmasina neden olan Faust'un ihtirası, bencilliği ve doyumsuzluğu, eserin ikinci kısmının sonlarında bu kez de yaşl1 çiftin ölüm nedeni olur.

Goethe bu eseri meydana getirirken, farklı teolojik metinlerden de yararlanır. Bu konuda özellikle İncil ve Tevrat ön plana çıkmaktadır. Nitekim eserde yaşlı çift ve Faust arasındaki bu olayla ilgili Tevrat'a atfen yapılmış değerlendirmeler de bulunmaktadır. Tevrat'ta İsrailoğulları'nın vaat edilmiş Kenan topraklarında hakimiyet kurmasından sonra, önceki yerleşimcilere ait ibadet yerlerini yok etmesi ve onları kovmalarının emredilmesi örneğinde olduğu gibi Faust, zaferin karşılığı olarak kendisine vaat edilen topraklarda hüküm sürmeye başladıktan sonra, önceki yerleşimcileri temsil eden yaşlı çifti yerinden edip, ölümlerine neden olur ve ibadet yerlerini de imha ettirir (Lämmert, 2011, s.99).

Eserin sonunda Faust, oldukça yaşlanıp, kör olmasına rağmen, hükmettiği topraklardaki işlerin aksamadan devam etmesi yönündeki arzusundan hiçbir şey kaybetmez. Öyle ki Mefistofeles'in emriyle Lemurlar, ölmediği halde Faust'un mezarını kazarken, bundan bihaber olan Faust, hendek kazıldığını zannederek, kazma seslerini işittiğinde oldukça mutlu olur ve hendeğin bir an evvel bitmesi için işçi sayısının arttırılmasını emreder. Tam da bu esnada Mefistofeles'ten kazılanın hendek değil, kendi mezarı olduğunu öğrenir. Faust ölmeden önce, sahip 
olduğu geniş toprakları, özgür halkın yaşayacağ1 özgür topraklar olarak nitelendirir ve son arzusunun da halkın birlik içinde kaynaşmasını görmek olduğunu belirtir ve akabinde hayata veda eder. Ölümünden sonra Mefistofeles "doyurmuyor hiçbir zevk onu, yetmiyor ona hiçbir mutluluk (...)" diyerek (Goethe, 2016, s.554), Faust'un açgözlülüğ̈̈ne ve doyumsuzluğuna dikkat çeker. Faust'un ölen bedeninden ruhunun ayrılmasını ve böylece ganimeti olarak gördüğ̈̈ ruhu ele geçirmeyi bekleyen Mefistofeles, gökten gelen meleklerin Faust'un ruhunu alıp göğe doğru yükselmeleriyle neye uğradığını şaşırır. Faust'un ölümsüz benliğini taşıyan melek, onun ruhunu kötülükten kurtardıklarını belirtir (Goethe, 2016, s. 568).

Birinci kısmın sonunda kurtuluşa eren Gretchen gibi ikinci kısmın sonunda bu kez de Faust kurtuluşa ermiştir. Ancak aralarında önemli bir farklılık vardır: Gretchen yaşadıklarından dolayı çokça pişmanlık duyup, tövbe eden biri olmasına rağmen, Faust arada küçük pişmanlıklar yaşar gibi görünse de bir tövbekâr değildir. Üstelik Faust'un uhrevi kurtuluşa ermesinin gerekçesi de 'canla başla çabalayan' bir birey olması şeklinde oldukça dünyevi bir nedene dayandırılır. Böylece bencilliği ve açgözlülüğü nedeniyle pek çok yıkım ve ölüme neden olan Faust'taki modern birey ruhu, taşıdı ̆̆ 1 etik sorunlara rağmen nihai noktada kutsanmış olur. Faust'un kurtuluşa ermesi ile ilgili yapılmış birbirine oldukça zıt değerlendirmeler ve tartışmalar bulunmaktadır. ${ }^{3}$ J. M. van der Laan (2007, ss.142143), meleklerden gelen sese atfen, Faust'un kurtuluşunun ilahi bir lütfun sonucu olduğunu belirtmektedir. Ancak gerek bu değerlendirme gerekse bu konuda yapılan diğer tartışmaların ötesinde, romantizm anlayışında modern bireyin içsel sesine kulak verip, kendini gerçekleştirme noktasında bir çaba içerisinde olmasının ve başkalarından farklılığ 1 ve eşsizliği temelinde, kendisine ait benzersiz deneyimi böylece ortaya koymasının önemsendiği dikkate alındığında, Goethe tarafında Faust'un kurtuluşa erdirilmesinin ve bu kurtuluşun onun çok çaba sergilemiş olmasına bağlanmasının daha farklı bir anlam kazandığını belirtmek gerekir.

\section{SONUÇ}

Edebiyat sosyolojisinin ana argümanlarından biri, edebi bir eserin oluşturulma sürecinde, edebiyatçının içinde yaşadığı toplumsal dünyadan bir şekilde etkilendiği ve toplumsal yapı ve toplumsal ilişkilerdeki gelişmelerin,

\footnotetext{
${ }^{3}$ Bu konuda bkz. Jaeger (1950) ve Pollak (1951).
} 
değişimlerin ve çatışmaların edebi eserin şekillenmesinde önemli bir rolünün olduğu yönündedir. Diğer bir ifadeyle, edebi bir eser, toplumsal dünyadaki nesnel gelişmelere dair yazardaki öznel deneyimin ve algının bir ürünü olarak ortaya çıkmaktadır. Goethe ve eserleri için de bu kuraldan bahsetmek mümkündür. 16. yüzyıldaki Alman Köylü Savaşları, 17. yüzyıldaki 30 Yıl Savaşları, Orta Çağ anlayışı kaynaklı sorunlardan kurtulmak için yapılan Reformasyon, Prusya' daki prensliklerin soylularla ve kendi aralarında yaptıkları egemenlik mücadeleleri, dönemin Avrupa'sında iki başat güç olan İngiltere ve Fransa'nın kendi ulusal birliklerini sağlamış olmalarına rağmen, Almanya'nın ulusal birliğinin sağlayamamış olması ve gerek siyasal gerek ekonomik açıdan bu ülkelerin gerisinde kalmış olması ve bu olumsuzluklardan kurtulmak noktasında ulusal çapta özgürlük, birlik ve dayanışma özlemi içerisinde olması gibi hususlar, Goethe'nin düşüncelerinin şekillenmesinde önemli rol oynamıştır.

Eskiden kopuşun yaşanmaya başladığı bir dönemde bilimsel, dinsel, kültürel, siyasal, toplumsal ve ekonomik alanlarda ciddi değişim ve dönüşümler ortaya çıkmıştır. Fransız İhtilali ve Sanayi Devrimi'nin Avrupa coğrafyası ile sınırlı kalmayan geniş etkileri de dikkate alındığında, modern dönemde yaşanan değişim ve dönüşümün sadece olumlu değil, bireysel hayatlara yansımaları bağlamında dramatik birtakım neticeleri de olmuştur. Geçiş çağındaki bu değişim ve dönüşüm bir yönüyle de bir kimlik krizine neden olmuştur. Nitekim kimlik sorununun Faust'un ana temalarından biri olması bu anlamda bir tesadüf değildir.

Goethe'nin neredeyse tüm hayatını adadı̆̆ 1 Faust'ta ele alınan sorunlar, sadece Faust'un yaşadığ 1 sorunlar olmayıp, bu süreçte Batılı bireyin yaşadığ1 dramatik durumu da temsil etmektedir. Dolayısıyla bu manzum tragedyada anlatılan aslında sadece Faust'un değil, başta Batılı birey olmak üzere tüm insanlığın dramıdır. Eserde; gelişimin ve özgürlüğün kaynağı olarak doğa ve kontrol alanı olarak toplumsal dünya, epistemeoloji ve ahlak ilişkisi, bilim ve sanat ilişkisi, doğayla kurulan ilişki biçimi ve bu ilişkiye yüklenen anlam sorunu, doğa ve insan eylemi arasındaki kopukluğu aşma arayışı, bilgi ve eylem arasındaki ilişki sorunu, insan benliğinde iyi ve kötü çatışması, bencillik ve özgecilik çatışması gibi pek çok farklı husus üzerinde durulmaktadır. Bir geçiş çağı eseri olarak Faust, modern bireyin gelişim sorunu ve hayatın çelişkili yönleri üzerine odaklanmaktadır.

Geleneksel değerlerden arındırılmış modern birey, geçmişten farklı olarak, başkalarına karşı sorumluluklar ve yükümlülükler odağında tanımlanmayan bir bireydir. Modernitenin toplumsal ve ahlaki değerlerden arındırılmış 'bağlantısız birey' tasarımı, bireysel özgürlügün temel teminatlarından biri olarak görülmüştür. 
Ancak bu konuda pratikte yaşanan deneyim, modernite ile ilgili bazı kaygıların da ortaya çıkmasına neden olmuştur. Araçsal akıl temelinde doğayla ve insanlarla kurulan sorunlu ilişki, ontolojik ve epistemolojik birtakım tartışmalara neden olmuş ve bireysel özgürlüğün kendisi de bu tartışmalardan etkilenmiştir. Bireyciliğin, hedonizmin ve tüketimin daha çok ön plana çıktığı modern toplumlar, bencil ve açgözlü birey tipinin, geçmiş dönemlerden daha çok görüldügü toplumlar olmuştur. Eserde modern bireyi temsil eden Faust'un gerek ilk kısımda gerekse ikinci kısımda, ana özelliklerinden biri, sahip olduğu arzuları gerçekleştirme doğrultusunda bencil, açgözlü ve doyumsuz bir kişiliğe sahip olması ve bu yönüyle pek çok yıkıma neden olmasıdır. Bu durum aynı zamanda bireysel gelişim sorununa işaret etmektedir.

Aydınlanmanın aklı ve bilimi kutsallaştıran yaklaşımına karşın, Goethe için birey sadece akıl sahibi bir varlık olarak değil, duygu sahibi bir varlık olarak önem taşımaktadır. Goethe açısından bilim, doğayı bilmenin/tanımanın aracı iken, sanat ise kendini bilmenin aracıdır. Özne ve nesne arasında doğru bir ilişki kurmak için gerek bilim gerekse de sanat bilgisi gereklidir. Goethe için toplumsal dünya temelde kontrole dayanırken, insan doğayla bütünleştiği oranda bireysel benliğini keşfedip, insani gelişim ve özgürlük yolunda ilerler. İyiliğin kaynağı olan doğayla bütünleşememe hali ise, benlik duygusunu ve bireysel gelişimi olumsuz etkileyecektir. Goethe'ye göre, kendini gerçekleştirme noktasında doğayla bütünleşip, içsel sese kulak verme, bireysel benliğin gelişimi açısından en doğru yol olarak gözükmektedir.

\section{KAYNAKÇA}

Adorno, T., Horkheimer, M. (2015). Sosyolojik açılımlar. (M. S. Durgun \& A. Gümüş, Çev.). Ankara: Bilgesu Yayıncılık.

Barry, D. (1992). Peninsular art: A context for a comparative study of Goethe and Joyce. Comparative Literature Studies, 29(4), 380-396.

Berman, M. (2013). Katı olan her şey buharlaşıyor. (Ü. Altuğ \& B. Peker, Çev.). İstanbul: İletişim Yayınları.

Boyle, N. (1992). Goethe: The poet and the age. Oxford: Oxford University Press.

Boyle, N. (2008). German literature: A very short introduction. Oxford: Oxford University Press. 

Yayınevi.

Butler, S. (2010). Tüm insanlar gibi. (N. Gökçe, Çev.). İstanbul: Epsilon

Cervantes Saavedra, M. de (2019a). La Mancha'lı yaratıcı asilzade Don Quijote I. (R. Hakmen, Çev.). İstanbul: Yapı Kredi Yayınları.

Cervantes Saavedra, M. de (2019b). La Mancha 'lı yaratıcı asilzade Don Quijote II. (R. Hakmen, Çev.). İstanbul: Yapı Kredi Yayınları.

Dikeçligil, F. B. (2017). Sosyal bilimlerde ontolojik öncül olarak insan, Sosyoloji Divant, 5(10), 189-218.

Eckermann, J. P. (2007). Yaşamının son yillarında Goethe ile konuşmalar. (M. Kahraman, Çev.). İstanbul: Türkiye İş Bankası Kültür Yayınları.

Fromm, E. (1982). Sahip olmak ya da olmak. (A. Arıtan, Çev.). İstanbul: Arıtan Yayınevi.

Goethe, J. W. V. (2016). Faust. (İ. Cankorel, Çev.). Ankara: Doğu Batı Yayınlar1.

Goethe, J. W. V. (2018). Wilhelm Meister'in çıraklık yıllarl. (F. Gürbüz Gerhold, Çev.). İstanbul: Alfa Yayınları.

Goethe, J. W. V. (2019). Genç Werther'in acıları. (M. Kahraman, Çev.). İstanbul: Türkiye İş Bankası Kültür Yayınları.

Günerigök, M. (2018). Risk toplumu ve din: Yeni bir sosyolojiye doğru. Ankara: Maarif Mektepleri.

Horkheimer, M., Adorno, T. W. (1995). Aydınlanmanın diyalektiği: Felsefi fragmanlar I. (O. Özügül, Çev.). İstanbul: Kabalcı Yayınevi. Yayınlar1.

Horkheimer, M. (1998). Akıl tutulması. (O. Koçak, Çev.). İstanbul: Ayrıntı

Ibsen, H. (2009). Peer Gynt. (J. Fillinger \& J. McFarlane, Trans.). Oxford: Oxford University Press.

Jaeger, H. (1950). The problem of Faust's salvation. in Goethe bicentennial studies by members of the faculty of Indiana University. Indiana: Indiana University Press, 109-152.

Kafka, F. (2020). Dönüşüm. (İ. Özdemir, Çev.). İstanbul: Yapı Kredi Yayınları.

Kant, I. (2015). Seçilmiş yazılar. (N. Bozkurt, Çev.). Bursa: Sentez Yayınları. 
Lämmert, E. (2011). The blind Faust. In Goethe's Faust: Theatre of Modernity, (H. Schulte, J. Noyes, P. Kleber, Ed.). Cambridge: Cambridge University Press, 94-112.

Lukacz, G. (2011). Goethe ve çăğ (F. B. Aydar, Çev.). İstanbul: Sel Yayıncılık. Lytton, E. B. (2010). Ernest Maltravers. Whitefish: Kessinger Publishing LLC. Mann, T. (2018). Doktor Faustus. (Z. Kurttekin, Çev.). İstanbul: Can Yayınları. Yayınları.

Marlowe, C. (2018). Dr. Faustus. (T. Y. Öğüt, Çev.). İstanbul: Mitos Boyut

Nietzsche, F. W. (2007). The birth of tragedy and other writings. (R. Speirs, Trans.). Cambridge: Cambridge University Press.

Pizer, J. D. (2011). Imagining the age of Goethe in German Literature, 19702010. New York: Camden House.

Plenzdorf, U. (2015). The new sorrows of young W. London: Pushkin Press.

Pollak, H. (1951). Some thoughts on the death and salvation of Goethe's Faust. Publication of the English Goethe Society, 21(1), 107-131.

Richards, R. J. (2002). The romantic conception of life: Science and philosophy in the age of Goethe. Chicago: The University of Chicago Press.

Schopenhauer, A. (2018). Yaşam bilgeliği üzerine notlar. (A. Nalbant, Çev.). İstanbul: Say Yayınları. Yayınc1lik.

Simmel, G. (2015). Bireysellik ve kültür. (T. Birkan, Çev.). İstanbul: Metis

Strich, F. (1949). Goethe and world literature. London: Routledge.

Sombart, W. (2016). Aşk, lüks ve kapitalizm: Modern dünyanın savurganlı̆̆ın ruhundan doğması üzerine. (N. Aça, Çev.). 3. Ankara: Pharmakon Yayınevi. Yayınları.

Spengler, O. (1978). Batı'nın çöküşü. (N. Şengebli, Çev.). İstanbul: Dergâh

Taylor, C. (2012). Benliğin kaynakları: Modern kimliğin inşası. (S. A. Baş \& B. Baş, Çev.). İstanbul: Küre Yayınları.

Taylor, C. (2014). Seküler çağ. (D. Körpe, Çev.). İstanbul: Türkiye İş Bankas1 Kültür Yayınları.

Van der Laan, J. M. (2007). Seeking Meaning for Goethe's Faust, London: Continuum. 
Modern Bireyin Bencilliği... DEU Journal of GSSS, Vol: 22, Issue: 4

Wagner, P. (2005). Modernliğin sosyolojisi: Özgürlük ve cezalandırma. (M. Küçük, Çev.). İstanbul: Ayrıntı Yayınları.

Watt, I. (2016). Modern bireyciliğin mitleri. (M. Doğan, Çev.). İstanbul: Boğaziçi Üniversitesi Yayınevi.

Weber, M. (1986). Sosyoloji yazıları. (T. Parla, Çev.). İstanbul: Hürriyet Vakfı Yayınlar1.

Weber, M. (1999). Protestan ahlakı ve kapitalizmin ruhu. (Z. Gürata, Çev.). Ankara: Ayraç Yayınevi. 